\title{
Duas faces do humor na poesia de Mário Quintana
}

\author{
Sergio Alves Peixoto \\ Universidade Federal de Minas Gerais
}

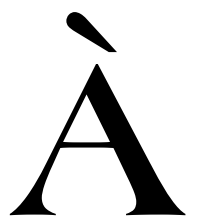

primeira leitura da obra de Quintana, um aspecto sobressai de imediato: a quase impossibilidade de qualquer situação séria deixar de ser contaminada por, pelo menos, um leve sorriso. E, dele, o poeta se vale, tanto para atacar, quanto para se defender.

O riso, como ataque, é, com certeza, a faceta mais conhecida de Quintana, por ser um riso mais popular, levando muitas vezes ao ridículo. E isso agrada mais facilmente ao público leitor. Com a ajuda dele, Quintana põe por terra a vaidade e a estupidez humanas, quase sempre fingindo que está só brincando.

Um dos alvos preferidos do poeta é o crítico. E, por extensão, o leitor que tudo pergunta ao poema e ao poeta. Quintana não perdoa o presumido status científico de certa crítica literária, nem os questionamentos do leitor, ambos querendo dar conta racionalmente do que deve ser entrega emotiva. É de se esperar, pois, que dirija a maioria de seus textos de cunho humorístico-irônico a eles.

No primeiro dos dois exemplos que selecionamos a seguir, os críticos aparecem como um bando de desajeitados que, procurando destrinchar o poema, se esquecem da poesia. Ao buscarem uma resposta científica para tudo, fixam-se unicamente na superfície da obra (suas estruturas sintagmáticas), perdendo a magia do encantamento poético. Não é à toa que o título do poema em questão é "O mago e os apedeutas": de um lado, o criador de mundos imponderáveis e enigmáticos; do outro, críticos e leitores perdidos à procura de explicações para a magia que se dá em meio à leitura, isto é, um bando de cômicos ignorantes, ou melhor, um ridículo charivari de apedeutas. Como explicar a construção desse castelo metafórico que se fez por si? - reflete o poeta. Como explicar a realização da poesia em palavras, quando o poema, segundo Quintana, jamais é uma fórmula algébrica e sim uma fórmula mágica? Vejamos o poema: 
"Não! Com certeza deve haver um truque!"

E ei-los que invadem, num charivari,

O meu Castelo

(que se fez por si)

Só para ver se não será de estuque...

$\mathrm{E}$

- um esfrega daqui, sopra outro dali -

O "material" é todo devassado.

O olho, por trás do pince-nez rachado,

Rebrilha frio como um bisturi.

Para livrar-me deles, nem morrendo!

Serão só uns ingênuos os sujeitos?

Não sei...

Mas em silêncio vou descendo

Ao mais profundo dos porões do Sonho

$\mathrm{E}$ entre as retortas mágicas me encanto

A cultivar sutil os meus defeitos.

(A vaca e o hipogrifo, p.40).

No texto em questão, um soneto disfarçado, os primeiros versos já encenam, de modo brincalhão, tanto a abordagem da obra pela crítica, quanto a leitura mais preocupada em querer saber o que o poema quer dizer, típica do leitor pelo qual Quintana nunca se interessou: crítico e leitor aqui se igualam na ignorância e na perda de tempo em tentar desvendar o mistério do poeta e da poesia. Ao final dessa leitura errônea e desses estudos falhos, os dois, para Quintana, sempre superficiais, resta ao poeta voltar ao "mais profundo dos porões do sonho", consciente de suas imperfeições, e jamais alheio à atividade improfícua e aborrecida desse inútil e bastante grotesco "charivari".

Pequeno exemplar da "bíblia do humor" de Quintana - o merecidamente famoso Caderno $\mathrm{H}$ - o texto "A borboleta" aparece, neste momento, como o segundo exemplo desses ataques dirigidos à crítica. Vemos, nele, contrapor-se o olhar do poeta e do verdadeiro leitor de poesia à pedante constatação do apedeuta presunçoso:

Cada vez que o poeta cria uma borboleta, o leitor exclama: "Olha uma borboleta!" O crítico, ajusta os nasóculos e, ante aquele pedaço esvoaçante de vida, murmura: - Ah!, sim, um lepidóptero...

(Caderno H, p.19) 
Se, no poema "O mago e os apedeutas", o crítico usava jocosamente um pince-nez, aqui ele porta nasóculos, palavras antigas e, por isso mesmo, acentuadoras do tom cômico e depreciativo com que são vistos estes pretensos cientistas. Para eles, a taxionomia é mais importante, e a borboleta-poema fica à mercê de algum alfinete que a espetará em páginas de livros de crítica literária, onde ficará, já sem vida, exposta aos olhos de curiosos como insetos em prateleiras de algum museu de história natural (ambos raramente visitados pelo público em geral).

Quando Quintana se refere à crítica, não devemos nos esquecer de que seus ataques se dirigem à crítica dogmática, isto é, àquela que procura explicar o poeta e o poema, ambos, para ele, inexplicáveis. E crítica dogmática rima, principalmente, com crítica estruturalista. Foi ela o alvo preferido do poeta, por ter-se querido dar ares de ciência, quando talvez não tivesse passado - vamos brincar um pouco - de uma espécie ineficaz de "engenharia mecânica". Na verdade, qualquer afirmação peremptória para Quintana sempre foi merecedora de seus ataques. Para ele, "a poesia não se entrega a quem a define". ${ }^{1}$

Três textos de Quintana, citados abaixo, mostram o poeta falando de si mesmo como um ser múltiplo e, por isso mesmo, infenso às certezas de leituras falhas, porque precipitadas e redutoras. Diríamos que foram escritos como respostas a essas análises e leituras equivocadas, desmerecendo a ambas. Nos três, a presença do humor:

(...) o poeta é uma criatura essencialmente dramática, isto é, contraditória, isto é, verdadeira. (Caderno H, p.21)

(...) se caso eu fosse ator e me visse enredado, ao representar Hamlet, naqueles seus dramas tremendos, não me apresentaria de preto, como o obrigam os diretores de cena, mas sim com as vestes coloridas e os guizos do seu amado bufão Yorick. Ah! Tudo isso porque tudo comporta o seu contrário; e a nossa alma, por mais que esteja envolvida nas coisas deste mundo, nunca deixa de estar do outro lado das coisas... (A vaca e o bipogrifo, p.19)

Não sou desses que um dia pensam uma coisa e no outro dia pensam outra coisa muito diferente.Eu penso as duas coisas ao mesmo tempo. Duas ou mais. Não tenho culpa de ser ecumênico. (Caderno H, p.94)

${ }^{1}$ Caderno H, 1973, p. 178. 
Se o poeta é dramático, é porque encerra em si o sublime e o grotesco, a seriedade e o riso. Se fosse um ator representando Hamlet, Quintana deixaria de lado o luto com que se apresenta o príncipe, para carnavalizar sua performance com vestes coloridas e guizos alegres. Assim, à melancolia do lânguido personagem, juntaria as gargalhadas e a balbúrdia de seu bufão. Nesses dois exemplos, como vemos, o humor não está explícito. No último deles, porém, o leitor sorri de imediato, porque o texto parodia certo discurso que escutamos quase que diariamente por muitas pessoas que conhecemos: "Não penso hoje uma coisa e outra amanhã". Isto é, "não mudo de opinião facilmente, tenho personalidade. Sou uma pessoa íntegra". Quintana, brincalhonamente ecumênico, pensa várias ao mesmo tempo. É homem e, por isso, fraqueja e se dispersa. O que resulta na fórmula: "Não sou Deus". Talvez por querermos ser Deus, já que fomos criados à Sua semelhança, é que os consultórios dos psicanalistas estejam constantemente cheios. Nos três exemplos, o que vemos é o homem e poeta se dando por inteiro na sua pluralidade.

Quintana nos diz que não teve escolha em relação à poesia. Chegou, no início, a escrever um conto intitulado "A sétima personagem", com o qual ganhou prêmio em um jornal de Porto Alegre, o Diário de Notícias. Entretanto, nunca se sentiu à vontade na prosa. A poesia se impôs, uma poesia feita de imaginação e fantasia. A prosa não era de seu feitio, obrigava-o à exatidão. Será que, por ser antes de tudo um jogo, a poesia seria capaz de mais facilmente acolher a brincadeira, o humor?

Um pequeno texto do poeta mostra essa concepção de poesia para Quintana, isto é, uma poesia que se faz de imaginação permeada pelo sorriso. Trata-se de "Suspense". Nele, a mera e simples constatação de uma aranha pendurada em sua teia cede lugar, inesperadamente, a um cenário fantasmagórico, mas não menos bem-humorado. Com ele, o poeta confirma certo adágio popular: o diabo não deve ser tão feio como parece:
A aranha desce verticalmente por um fio e fica pendendo do teto - escuro candelabro: devem ser feitas de aranhas, desconfio, as árvores de Natal do diabo.

(A vaca e o bipogrifo, p.44)

Se a prosa deveria ser enxuta, a poesia poderia dar-se ao luxo de espraiar-se, ir para lugares outros onde a lógica do raciocínio seria abolida, viver de, pela e para a imagem. 
Numa fórmula bastante conhecida dos leitores de Quintana, a poesia passa a ser a invenção da verdade. E, ao falar dela e de suas tentativas como prosador, o humor reaparece para quebrar a possibilidade de uma reflexão melancólica sobre a perda de uma ilusão: a ilusão de ser votado à prosa. Não podemos nos esquecer que Quintana foi excelente tradutor de romances, ${ }^{2}$ e de que o Caderno $H$, A vaca e o bipogrifo e Sapato florido ${ }^{3}$ são três excelentes livros de prosa... poética, é claro.

Bem que eu gostaria de escrever contos. Mas isso de enredo me parece uma coisa para comadres... O que não deixa de ser uma contradição da minha parte, porque ainda penso que o conto deve ser para contar alguma coisa.

- Ora - dirás - e o conto de atmosfera?

- Sim, sim... Mas por que não ficamos então na poesia?

Para mim, o que há de mais perfeito no gênero narrativo é, obviamente, o conto policial no estilo enxuto e sem imagens das imortais histórias de Sherlock Holmes. A imagem atrapalha, distrai, desvia... Lembro-me de quando estava uma vez lendo uma história de Rémy de Gourmond e lá pelas tantas falava ele de certa moça que tinha uma voz tão suave e tão do outro mundo que, se ela dizia "está chovendo", parecia que estava chovendo anjos... Não continuei, não pude, nada mais poderia encantar-me tanto. Viva, pois, Somerset ou Mérimée, que têm a coagem do despojamento e da pobreza voluntária.

Eu não. Remexendo nuns papéis velhos, encontrei uma história que começava assim:

"Era um dia de verão, um desses dias em que dá na gente uma vontade infinita de se pendurar num cabide e ali deixar-se ficar para sempre, como um velho casaco de ombros caídos, de braços pendidos, sem ninguém por dentro!"

Tudo isso porque não tive coragem de dizer simplesmente, para início de conversa:

"Era um insuportável dia de verão".

Outra coisa que me impediu em tempo o cultivo do gênero é que meus personagens não sabiam revelar indiretamente seus pensamentos e sensações, como acontece na vida. Um deles certa vez saiu-me com esta:

${ }^{2}$ Dentre os diversos autores que traduziu, encontram-se Voltaire, Papinni, Virginia Woolf, Balzac e Proust.

3 Sapato florido é de 1948. 
"O toque do despertador é um acidente de tráfego do sono. Por isso passamos o dia inteiro confusos como acidentados... até que chega a hora do aperitivo."

Claro que numa conversa toda assim, durante páginas, deixaria o leitor em estado de choque. (Caderno H, p.180)

Frente à perda das ilusões, o que fazer? Chorar, lamentar-se? Até que um pouco, talvez. Mas sorrir da vida é mais produtivo, como mostra a excelente quadrinha de seu livro Espelho mágico, título exemplar, pois um espelho comum só nos devolve a superfície das coisas, enquanto que a magia deste outro possibilita nos vermos e ao mundo em outras dimensões, principalmente as dimensões que o humor nos oferece e que ele sabe tão bem desvelar a nossos olhos cheios da mesmice desta vida que nos vendem como verdadeira.

Neste momento, no reflexo deste mágico espelho, surge a outra face do riso de Quintana à qual nos referimos no início deste artigo: uma arma de defesa. O poeta defende-se da angústia frente à passagem do tempo, da frágil existência humana, do sofrimento inelutável em face das desilusões e da presença da morte. Para ele, se a existência é fugaz, o homem contraditório, o mundo instável e a obra fragmentada, por que deveríamos levar a vida e seus problemas tão a sério? Vejamos essa quadrinha "filosoficamente revolucionária":

Meu saco de ilusões, bem cheio tive-o.

Com ele ia subindo a ladeira da vida.

E no entretanto, a cada ilusão perdida

Que extraordinária sensação de alívio.

(Poesias, p.115)

Nestes momentos é que Quintana nos toca mais. O poeta perde muitas vezes, o agudo aço da ironia, ou mesmo a força de sua veia cômica, para se deixar invadir por um humor que não mais ataca, mas serve de escudo à angústia da existência. Finalizamos, então, nosso trabalho, com um dos mais belos de seus poemas, um grande momento da obra de Mário Quintana: a "Canção de garoa":

Em cima do meu telhado,

Pirulin lulin lulin

Um anjo todo molhado

Soluça no seu flautim. 
O relógio vai bater

As molas rangem sem fim

$O$ retrato na parede

Fica olhando para mim.

E chove sem saber por quê...

E tudo foi sempre assim!

Parece que vou sofrer...

Pirulin lulin lulin

(Poesias, p.36)

Como tudo em Quintana, a viagem pela imaginação se dá no presente poema. Não é de um dia chuvoso que ele quer falar, mas de uma alma anuviada de poeta. Então, ao som monocórdio da garoa renitente, superpõe-se a visão de um anjo com seu flautim soluçante. As gotas que caem do telhado são notas melancólicas, mas nem tanto: o refrão (lulin/ lulin/lulin) provoca um certo sorriso, principalmente se "vemos" a figura encharcada de um anjo que perdeu toda sua aura divina trepado no telhado da casa do poeta. Não há mais asas pandas e posições hieráticas neste anjo, que no mínimo deve ser parente daquele dentuço de um outro poema, ou do que nasceu, apressadamente, com uma das asas no traseiro. Da visão do anjo e da apresentação da cena, ambos envolvidos pela melancólica garoa, passamos, na segunda estrofe, ao interior da casa. Conseqüentemente, para o interior do poeta. O termo "tempo" agora é outro: não mais o que se refere a mudanças climáticas, o que nos diz se vai fazer frio ou calor, se chove ou se faz sol, mas o tempo da vida que escoa juntamente com os ponteiros do relógio da parede. Este "animal terrível”, que, em outro texto de Quintana, já matou vários membros de sua família, está prestes a anunciar - pelas batidas de sua pêndula menos um instante de vida, mais uma etapa no sofrimento que é viver. O ranger das molas conjuga-se ao som das goteiras lá fora. Na parede, um retrato que o olha. No retrato, não o tempo parado, mas o anúncio do tempo que já passou e continuará a passar. Retrato de um morto, com certeza. Nos tempos de antanho, era comum fixar nos retratos o rosto e o olhar dos que já se foram, deixá-los nas paredes, como a dizer que o morto ainda está presente neste mundo, pela memória e por sua imagem fixada, mas também que o outro mundo nos aguarda. O retrato na parede anuncia, como o relógio, o fluir temporal, os passos de sua morte. A última estrofe da canção deixa transparecer a perplexidade do eu em relação ao eterno passar do tempo. Como eterna parece ser a garoa. "E 
chove sem saber por quê/E tudo foi sempre assim", diz o poema. Tudo: a garoa, a vida que se deixa escoar pelos dedos. Logo em seguida, passase da mera constatação ao sofrimento em face da existência. O verso "Parece que vou sofrer" é irônico. Não parece: já se está sofrendo. Sempre se sofreu (e tudo foi sempre assim). Tudo muito triste, não? Sim... Mas o último verso traz de volta a música ritmada do flautim, vazada na redondilha menor, que foi a forma escolhida pelo poeta, como se ele nos quisesse dizer que devemos, bem popularmente, "levar a vida na flauta". O humor não elide a melancolia dessa canção de garoa, mas faz com que vivamos a vida com mais leveza.

Um dos mais importantes poetas-filósofos da Ironia romântica alemã, Friedrich Schlegel, escreveu, nos "Fragmentos do Athenaum", que "Não há nada mais desprezível que um espírito triste". ${ }^{4}$ Quintana, na poesia de língua portuguesa, é, certamente, um dos mais importantes herdeiros dessa linhagem.

\section{Referências Bibliográficas}

QUINTANA, Mário. Caderno H. Porto Alegre: Globo, 1973. . A vaca e o hipogrifo. Porto Alegre: Garatuja, 1977. Poesias. Porto Alegre: Globo, 1975. A coletânea inclui os cinco primeiros livros do poeta: A rua dos cataventos(1940), Canções (1946), Sapato florido (1948), O aprendiz de feiticeiro (1950) e Espelho mágico (1951).

SCHLEGEL, Friedrich. Fragments de l'Athenaum. In: LACOUE-LABARTHE, Philippe et NANCY, Jean-Luc. L'absolu littéraire. Paris: Seuil, 1978.

${ }^{4}$ In: LACOUE-LABARTHE et NANCY, 1978, p. 17. 


\section{Resumo}

A poesia de Mário Quintana, vista pelo viés do humor, tanto como arma de ataque à crítica dogmática e ao "leitor-crítico", quanto como forma de defesa contra os percalços da existência.

\section{Résumé}

La poésie de Mário Quintana, vue par le biais de l'humour, et comme ataque aux critiques dogmatiques et aux "lecteurs-critiques", et comme défense contre la douleur de vivre. 